\title{
A NEW SPECIES OF SELENIPEDIUM (ORCHIDACEAE: CYPRIPEDIOIDEAE) FROM ECUADOR
}

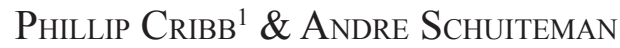

\author{
Royal Botanic Gardens, Kew, Richmond, Surrey TW9 3AB, U.K. \\ ${ }^{1}$ Author for correspondence: P.Cribb@kew.org
}

\begin{abstract}
A new species of Selenipedium (Orchidaceae: Cypripedioideae) from northern Ecuador is described here and its affinities are discussed. A key to the known species of the genus is provided.
\end{abstract}

KeY wORDS: Selenipedium, slipper orchid, Ecuador, new species, dichotomous key

Selenipedium, a small genus of slipper orchid (Orchidaceae: Cypripedioideae) whose range extends from Panama south to Ecuador and east to Trinidad, French Guiana and eastern Brazil, is the basal clade in the subfamily Cypripedioideae. It has recently been revised by Cribb (2009). The seven currently recognised species of Selenipedium are very closely allied to each other, having tall bamboo-like stems bearing alternate pleated leaves and terminal inflorescences of successively produced small flowers with a trilocular ovary, a dorsal sepal, similar synsepal, comprising the connate lateral sepals, two tapering lateral petals and a simple obovoid to ellipsoidal somewhat dorsiventrally flattened deeply concave lip with incurved lateral lobes and an incurved margin to the much larger apical lobe (except in the semi-peloric S. chironianum). The column is short with two large bilocular stamens on short filaments, a linear to trullate staminode and a pendent trilocular papillose stigma. The best known species is S. palmifolium Rchb.f. widespread on the Guiana Shield from Venezuela, Guyana, Surinam, French Guiana and northern Brazil. The other six species are much more restricted in range: $S$. aequinoctiale Garay in north-western Ecuador and adjacent Colombia; S. chica Rchb.f. is endemic to Panama; S. chironianum Sambin \& Braem (2015) from French Guyana; S. isabelianum Barb. Rodr. from eastern Brazil; S. steyermarkii Foldats from Venezuela; and S. vanillicarpum Barb. Rodr. from Goias State in Brazil where it is known only from the type collection.

Calaway Dodson (1999) recognised two species of Selenipedium in his checklist of the Orchidaceae for Jørgensen \& Leon-Yánez's Catalogue of the Vascular
Plants of Ecuador. One of these, Selenipedium aequinoctiale, was described from northern Ecuador, whereas he identified the other, based on a sterile specimen from Succumbios Province in northeastern Ecuador (cited as Davis 1048 at AMES), as $S$. chica, a species previously considered to be endemic to Panama. Later, Dodson (pers. comm.) sent an updated manuscript to Kew in which he listed a further two collections of this taxon from Pastaza Province, to the south of Succumbios. Perez-Garcia and Mó Mó (2015) recently published a photograph of this orchid by Francisco Tobar under the name $S$. chica. It differs from $S$. aequinoctiale in having a somewhat differently colored flower with a lip with a narrower margin around the orifice and a much larger trullate staminode that is about a third the width of the lip base (rather than less than a quarter the width). It is certainly not $S$. chica which has much longer and narrower leaves and distinctively colored flowers in which the ovary is glabrous, the petals are trinerved and the staminode is spathulate not trullate (Dressler, 1993). The only other candidate for this species is $S$. palmifolium. However, that species differs in having a dorsal sepal that is much narrower than the lip, an obovoid lip with yellow incurved side lobes that just touch in the middle rather than all along the margins and an elliptic orifice marked with purple around the apical two-thirds of the rim and a smaller triangularcordate staminode.

Only one of the collections (Holguer Lugo S. 5538 at AMES) cited by Dodson in his unpublished account is fertile and that specimen is the basis for the following description. 


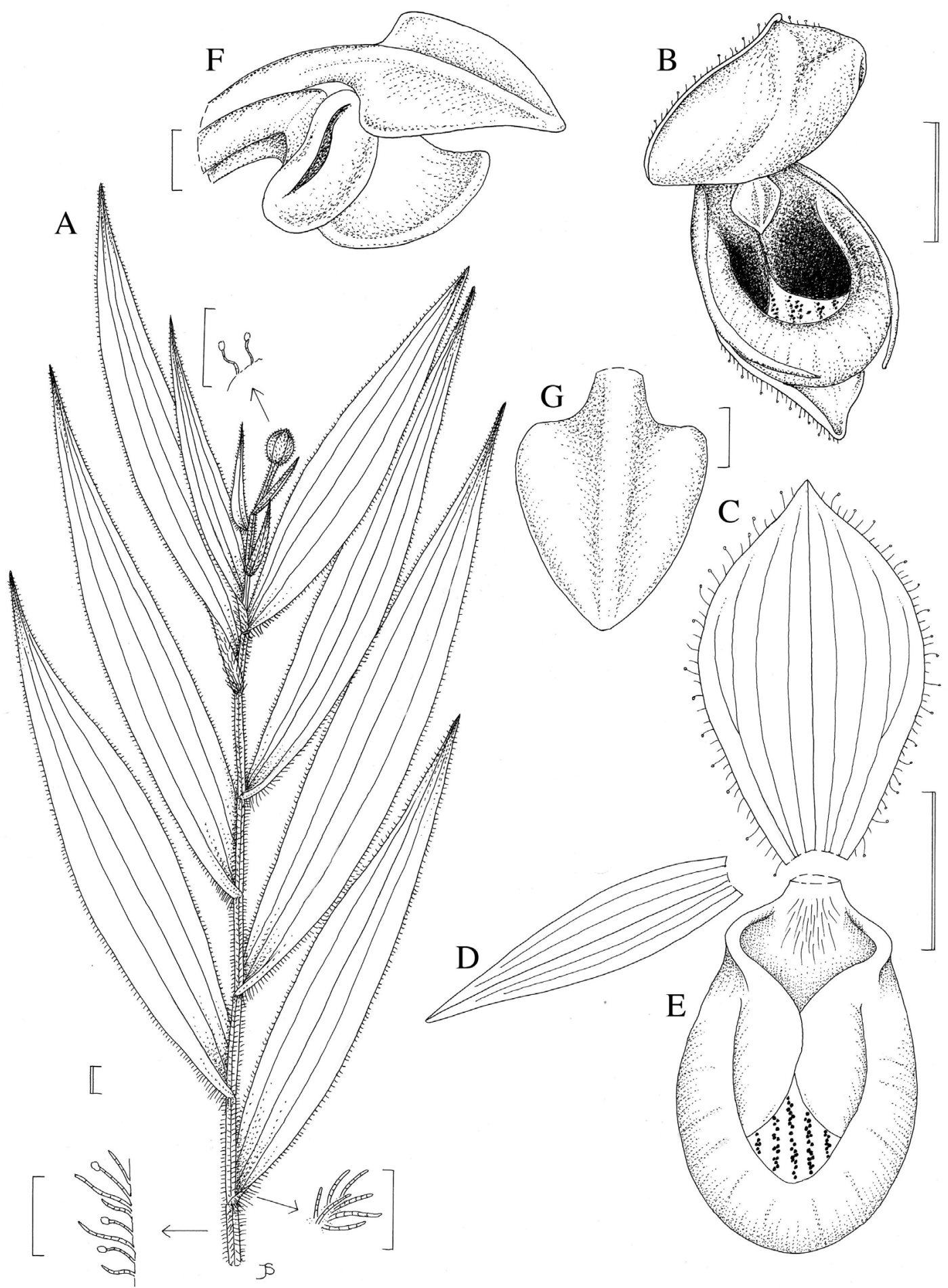

FiguRE 1. Selenipedium dodsonii P.J.Cribb. A, habit; B, flower; C, dorsal sepal; D. petal; E, lip; F, column, side view; G, staminode.

Double bar $=10 \mathrm{~mm}$; single bar $=1 \mathrm{~mm}$. All drawn by Judi Stone from the type and photographs by Francisco Tobar Suarez. 


\section{Selenipedium dodsonii P.J.Cribb, sp. nov.}

Selenipedio palmifolio Rchb.f. affine sed floribus tristis flavis lobis oblongibus labello elliptico quam sepalo dorsali aequantibus lobis lateralibus labelli purpureis (vs luteis) et staminodio triangulare distinguendo; a $S$. aequinoctiale Garay sed lobis lateralibus labelli longioribus quam latioribus et staminodio grandiore trullato et a $S$. chica Rchb.f. foliis latioribus 4-6plo longis quam latis sepalo dorsali brunneis labello obovato et staminodio trullato satis differt. TYPE: Ecuador, Pastaza, Holguer Lugo S. 5538 (holotype AMES!; sketch of type at $\mathrm{K}$ !).

A terrestrial herb with erect, terete, leafy stems up to $3 \mathrm{~m}$ tall, often sparsely branching above; stems dark green, covered by coarsely and densely villose leaf-bases. Leaves narrowly elliptic-lanceolate, acuminate, cuneate at base of lamina, 17-20 cm long, $2.8-3.8 \mathrm{~cm}$ wide, dark green, glabrous above, sparsely pilose at base, about 8-nerved, ciliate, sheathing at base; sheaths minutely puberulent. Inflorescence terminal or from axils of upper branches, up to 15 cm long, densely few-flowered; bracts chartaceous, ovate, acute or subacuminate, $10-30 \mathrm{~mm}$ long, 3-4 mm broad, pubescent, ciliate. Flowers small, produced in succession; sepals and petals light dull yellow, lip yellow, finely spotted with purple within and with two large maroon marks on the incurved side lobes; pedicel and ovary $30-50 \mathrm{~mm}$ long, densely glandular-pubescent. Dorsal sepal elliptic, acute, 22-25 mm long, 13-14 mm broad. Synsepal ellipticovate, shortly bidentate at apex, 20-24 mm long, $16 \mathrm{~mm}$ broad. Petals slightly obliquely narrowly lanceolate, acute, up to $24-25 \mathrm{~mm}$ long, $4 \mathrm{~mm}$ broad, 5 -veined. Lip calceolate, broadly elliptic in outline, 17-20 $\mathrm{mm}$ long, $12-13 \mathrm{~mm}$ broad; inflexed basal margins rounded; side lobes broadly semi-elliptic, overlapping on incurved margins. Column $5 \mathrm{~mm}$ long; staminode stalked, cordate, acute, $4 \mathrm{~mm}$ long, $2 \mathrm{~mm}$ broad, yellow, longer than the obtriangular, papillate stigma; anthers large, $2 \mathrm{~mm}$ long. Fruits not seen. Fig. 1-2.

Distribution. N Ecuador (on Amazonian side of Andes).

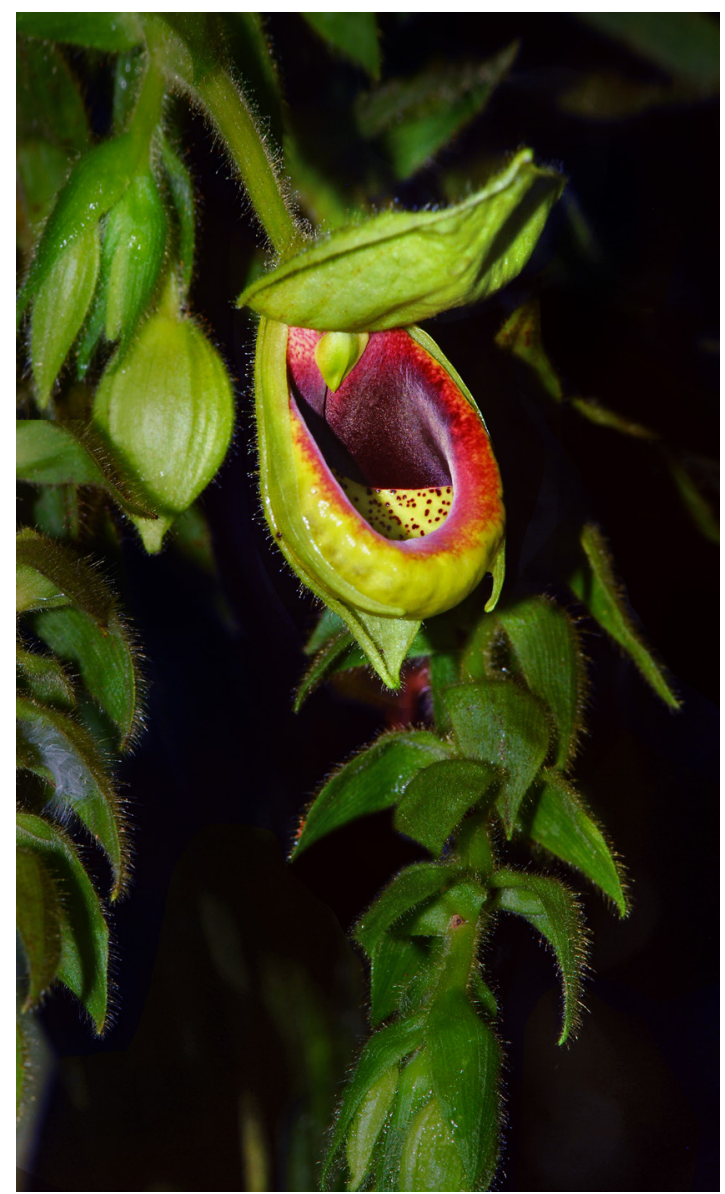

Figure 2. Selenipedium dodsonii. Photographed in situ at Archidona, Napo Province in Ecuador by Francisco Tobar.

HaBitat. In damp scrub near rivers in rain forest; 200$900 \mathrm{~m}$ elevation. Flowering April-November.

Conservation. Under the IUCN Red Listing criteria (IUCN 2012), Selenipedium dodsonii must be classified as Endangered (EN), based on criteria B1a and $\mathrm{B} 2 \mathrm{a}$.

Collections. Succumbios, Rio Quiwado and Rio Tiwaeno, 200 m, 28 April 1981, E.W. Davis \& Yost 1048 (AMES!); Pastaza, Pozo petrolero 'Namoyacu' de UNOCAL, $30 \mathrm{~km}$ al sur del pueblo de Curaray, 290 m, 13-30 Nov. 1990, S. Espinoza \& T Coba 670 (MO!, OCNE!). Napo, Archidona, Hakuna Matata Lodge, 900 m, F. Tobar Suarez (photograph only, copy at K).

The key below can be used to distinguish the species. 
1. Lip petal-like; anthers three

1a. Lip saccate; anthers two

2. Largest leaves more than 6 times as long as broad.

3. Leaves 6-7 times as long as broad; bracts shorter than the pedicel and ovary; ovary not glandular; petals 3-nerved; lip orifice elliptic-subcircular

3a. Leaves 8-10 times as long as broad; bracts as long as or longer than pedicel and ovary; ovary glandular; petals 5-nerved; lip orifice angular across base and broadest in basal half

S. steyermarkii

2a. Largest leaves less than 6 times as long as broad

4. Lip incurved side lobes overlapping beneath the staminode

5. Lip side lobes more or less as long as broad; staminode a quarter the width of the lip base; dorsal sepal yellow marked with fine purplish flecks

S. aequinoctiale

5a. Lip side lobes longer than broad; staminode a third the width of the lip base; dorsal sepal yellow

S. dodsonii

4a. Lip side lobes not overlapping beneath the staminode

6. Lip lilac

S. vanillicarpum

6a. Lip greenish yellow, yellow, brown or orange, with purple marking on apex of side lobes or margins of orifice of the lip

7. Leaves densely villose below, glabrescent above, ciliate on margins; sheaths pubescent; bracts longly glandular villose; ovary shortly pubescent, glandular at apex; petals 5-nerved; lip 1.251.52 times as long as broad, yellow or brownish yellow maroon-marked around the apical twothirds of the orifice; staminode triangular-trullate, as broad as long

S. palmifolium

7a. Leaves sparsely pubescent beneath, glabrous above and on margins; basally ciliate; sheaths glabrous; petals 1- to 3-nerved; bracts not glandular; ovary pubescent on ribs, not glandular at apex; lip 1.6 times or more longer than broad, orange with two maroon marks near the apex of the orifice; staminode deltoid, longer than broad

S. isabelianum

Acknowledgements. We would like to thank Gustavo Romero at AMES for the loan of the type material; Francisco Tobar Suarez of Quito very kindly allowed us to use his photographs taken in the wild; Judi Stone provided the excellent black and white line illustration.

\section{LITERATURE CITED}

Cribb, P. J. (2009). The genus Selenipedium. Curtis's Botanical Magazine, 26(1-2), 5-20.

Dodson, C. H. (1999). Selenipedium Rchb.f. In for Jørgensen \& Leon-Yánez, eds., Catalogue of the Vascular Plants of Ecuador Cypripediaceae. Missouri Botanic Garden Press.
Dressler, R. L. (1993). Field Guide to the Orchids of Costa Rica and Panama. Comstock Publishing Associates, Ithaca, New York.

IUCN. (2012). IUCN Red List Categories and Criteria: Version 3.1. Second edition. Gland, Switzerland and Cambridge, UK: IUCN.

Perez-Garcia,A.\& Mó Mó, E.A.(2015). Die Cypripedioideae von Mesoamerika Teil 1 Selenipedium. Die Orchidee, 66(1), 54-67.

Sambin, A. \& Braem, G. (2015). Selenipedium chironianum, une intéressante addition à la flore des orchidées de Guyane française. Richardiana, 15, 183-187. 